Julita ŁUKOMSKA, PhD

Faculty of Geography and Regional Studies, University of Warsaw

e-mail: j.lukomska@uw.edu.pl

ORCID: 0000-0003-3796-7314

Jarosław NENEMAN, PhD

Faculty of Economics and Sociology, University of Lodz

e-mail: neneman@uni.lodz.pl

ORCID: 0000-0003-0865-4706

DOI: $10.15290 /$ oes.2020.04.102.04

\title{
URBAN SPRAWL AND THE FINANCIAL STANDING OF MUNICIPALITIES ${ }^{1}$
}

\begin{abstract}
Summary
Purpose - Without undertaking a comprehensive assessment of the costs and benefits of the urban sprawl, this article attempts to analyse the impact of this phenomenon on the financial standing of municipalities.

Research method - We have primarily used difference-in-differences (DiD) regression analysis with reference to the treatment group (suburban municipalities) and the control group (other municipalities excluding cities with county status). The research was undertaken during the years 2004-2018 and used financial data from the Ministry of Finance.

Results - Urban sprawl is a beneficial phenomenon, at least in the short and medium term from the perspective of the financial standing of municipalities (which experience an inflow of new residents). It is clearly evidenced in the revenues of the budgets of suburban municipalities, i.e. an increase in both total and per capita revenues in relation to the control group. The effect of suburbanisation is also visible on the spending side, although, due to the economies of scale, current expenditures grow relatively slower than the number of inhabitants. The operating surplus of the budget per capita is increasing more rapidly in suburban municipalities compared to the control group. The same is true for municipal investment expenditures.

Originality / value / implications / recommendations - In reviewing the subject literature, the issue of the impact of urban sprawl on the finances of local government units (LGU) is treated marginally and indirectly, e.g. when discussing the costs of providing local public services. This article aims to present a synthetic and quantitative review of the impact of suburbanisation on the financial position of LGU budgets, comparing the situation of suburban municipalities to other municipalities. Attracting "new" residents is a desirable strategy in the development of municipalities, hence with the current system of
\end{abstract}

1 Article received on 24 March 2020, accepted on 29 May 2020.

The research has been conducted within the project "New model of urbanisation in Poland - practical implementation of the principles of responsible urbanisation and compact city (Gospostrateg 1/384689/20/NCBR/2019) co-funded by the National Centre for Research and Development within the Strategic Research and Development Programme "Social and economic development of Poland in the conditions of globalising markets" - GOSPOSTRATEG". 
financing, LGUs are likely to oppose changes aimed at limiting or controlling the suburbanisation process.

Keywords: suburbanisation, consequences of urban sprawl, financial standing of municipalities, Poland

JEL Classification: H71, H72, R51

\section{Introduction}

The phenomenon of urban sprawl (or city sprawl), also referred to as exurbanisation [Nowak, 2015, p. 133], is a spontaneous process of residents moving to the suburban municipalities accompanied by a relocation of part of the functions of the central city. It is its spontaneity and unplanned character that distinguishes urban sprawl from suburbanisation [Lityński, 2019, p. 21]. This occurrence is commonly perceived as negative [see e.g. Burchell et al., 2002; Kowalewski et al., 2014]. Attention is drawn to its spatial, economic, social, and environmental costs [Gliwiński, 2018], while the subject literature focuses mainly on its environmental, urbanisation and social aspects.

However, purely economic consequences of this phenomenon remain on the sidelines. They can be seen from the perspective of individuals, or more often families, who move out of the city, although they still have a lot in common with the city (e.g. work, school, health care, culture, shopping, etc.). In this case, the benefits result predominantly from improved housing and living space, and also proximity to nature, while the main additional cost component is the cost of transport. Based on tax returns for 2006, the Central Statistical Office (GUS) estimated, that the costs for commuters travelling more than 5 kilometres a day amounted to 25.9 billion zlotys a year. According to 2010 data from the Labour Force Survey (LFS, in Polish: BAEL), for people whose one-way travel time was more than 30 minutes, it was estimated that the total travel time amounted to 610 million man-hours per year, which when multiplied by the average net salary amounts to 8.4 billion PLN per year [Kowalewski et al., 2014, pp. 116-117]. Lityński and Hołuj [2017, p. 15] estimated these costs for Polish agglomerations; on average, a household loses 4.1 thousand euros, of which 2.4 thousand euros are direct costs, and 1.7 thousand euros can be attributed to the costs of time lost to travel. If the awareness of these costs had been higher, it is possible that the willingness of residents to move out of cities may have been lower. The dynamics of urban sprawl in developed countries (including Poland) shows that individual benefits exceed costs [EEA, 2006]. The benefits of suburbanisation are largely private and the costs are largely public, which is due to the fact that some of them have the character of externalities [Brueckner, 2001, p. 67]. An additional reason is the imperfect legal regulations. As a result, a significant portion of the general settlement costs is borne by other residents or taxpayers [tukomska, Neneman, 2020]. Lisowski and Grochowski [2008, p. 27] view the sources of difficulties in solving the issue of urban sprawl as a conflict between the 
private (particular) benefits of the settlers (who gain the desired housing conditions), investors, land sellers, and the surrounding municipalities (who gain additional tax revenues), and the social rationality resulting from increased energy-consumption, terrain-consumption, cost-consumption, as well as environmental and landscape degradation.

On a national scale, the advantages and costs of suburbanisation can be seen from the financial perspective of municipalities, as this process takes place in their territory and they benefit from it; however it also incurs costs. Therefore, it is necessary to analyse its impact on LGU revenues and expenses. Lukomska and Neneman made such an attempt in their work [2019, 2020].

In general, the subject literature compares the situation of suburban municipalities to the position of the central city [Orfield, 2002; Smutek, 2016], although an interesting study by Lityński was published recently [2019] in which the author makes a comprehensive analysis of the effects of this phenomenon on local government finances. However, his analysis is purely based on data from 2015-2017, which seems to be too short a period of time to demonstrate any long-term consequences of city sprawl. Our study analyses lengthier periods and, in contrast to the analyses of Smutek [2016], attempts have been made not only to indicate the occurrence of the phenomenon, but also to estimate its impact on the financial situation of municipalities.

The aim of this work is to estimate the effect of suburbanisation on selected aspects of local government finances. Our hypothesis is that in suburban municipalities the financial situation constantly improves with the influx of residents in comparison with the situation in other municipalities (excluding cities with county status). With respect to investment expenditures of municipalities, it should be expected that due to increased investment needs (related to "new" dispersed land development and expectations of settlers), outlays on investments in suburban municipalities increasingly exceed such expenditures in other municipalities.

Our analyses are based on data from the years 2004-2018. The suburbanisation process has significantly accelerated after Poland's accession to the EU, which is mainly due to the rapid GDP growth rate as the wealth growth is an important driver of this phenomenon. A new system of financing for local government units (LGUs) introduced this year is also significant as this ensures comparability of data.

\section{Urban sprawl and the financial standing of municipalities}

Urban sprawl has a significant impact on the financial situation of the suburban municipalities: it causes a change in the LGU's total revenues and their structure and also impacts their expenditures, although to a different extent.

As far as income is concerned, municipalities located adjacent to cities are beneficiaries of the city sprawl, while the central cities incur loses [Smutek, 2016]. This is because the system of LGU's financing is based on revenues from participation in PIT and real estate tax, so the tax revenues "follow" the moving 
inhabitant. The increase of PIT revenues is naturally strongly correlated with the increase in the number of residents, and more specifically, with PIT taxpayers, as shown for the Lublin agglomeration [tukomska, Neneman, 2019]. A significant increase in the absolute income value is not always accompanied by increases of its value in relative terms, e.g. per capita.

The change in the number of inhabitants also affects spending, although it appears differently in the central city compared to the suburbs. Some of the costs of municipalities are fairly constant and change only slightly with the change in the number of inhabitants; as a result of the "natural monopoly" 2 . In such circumstances, we are dealing with the benefits of the economies of scale, i.e. with a greater number of services or goods provided, their average cost is lower.

The growth in the number of inhabitants is associated with an increase in some of the costs, especially investment costs in suburban municipalities. However, this growth may be in many categories lower than the growth rate of the number of inhabitants, so it may decrease per capita. The main expenditure for the municipalities is education. Formally, they are covered by an educational subsidy, however it is insufficient. The cost and benefit analysis for the financial situation of municipalities in the context of educational expenses is multi-faceted and not at all obvious. In general, the larger the number of children is in schools, the higher the amount of the subsidy for education received by the municipality. However, the unfavourable demographic trends observed in recent years has caused the number of pupils to fall, which subsequently results in a decrease in the number of students per one class and thus a significant increase in costs per pupil ${ }^{3}$. The cost of education in a class of 15 pupils is almost the same as in a class of 25 . This means that additional students can be a benefit to the municipality as they reduce unit costs. They also help to avoid the unpopular decisions to close schools. Central cities can also benefit from this by "attracting" pupils from suburban municipalities, so that schools do not have to be closed down and teachers made redundant, and in order to reduce the costs per student. This strategy is successfully implemented in Lublin [tukomska, Neneman, 2019]. The cost benefits, i.e., a decrease in the average cost, may also occur in other types of expenditures, such as administrative expenses or maintenance costs of local roads. In general, the higher the population density, the easier it is to achieve economies of scale [Elis-Williams, 1987; McGuire, Sjoquist, 2002; Burchell et al., 2002]. Urban sprawl means, on the one hand, an increase in the total cost of providing public services (resulting from the relocation of residents to less densely populated areas) and, on the other hand, local costs per capita may decrease due to a growing population. This means that with the increase in the number of inhabitants of suburban municipalities, a decrease in expenditure per capita should be

\footnotetext{
2 Decreasing average costs may concern public administration services, education, pre-school care, 'communal services' (including water and sewage, solid waste collection, street lighting, local parks and green areas etc.), health care, although some of them depend on the nature of the settlement; dispersed settlement may cause an increase of the average cost of e.g. 'communal services'.

${ }^{3}$ Education is an example of a service where fixed costs dominate.
} 
expected. This certainly applies to current expenditures, while investment expenditures per capita may increase [Smutek, 2016, p. 116]. The balance of benefits and costs of a suburban municipality depends to a large extent on the costs of infrastructure development and maintenance, and this is determined by the type of settlement: compact or dispersed. An interesting analysis was conducted in Austria which showed that the financial situation of the municipality may deteriorate if the settlement is dispersed [Humer et al., 2019].

Lityński [2019] made an attempt to assess the balance of benefits and costs for the settlement municipalities, and concluded that the increase in PIT revenues in suburban municipalities is accompanied by a decrease in revenues from the general grant (i.e. lower dynamics of the total revenue growth) and an increase in expenses (especially investment expenses), which in the long-term will worsen the financial situation of the municipality. The more dispersed the spatial development structure of the municipality is, the stronger such deterioration will be.

A certain dichotomy between experts' opinions [see Lityński, 2019] emphasising greater costs than benefits of suburbanisation and the strategies of municipalities aimed at attracting new residents can be explained in many ways. Perhaps the municipal authorities are not able to make a full cost-benefit analysis, or maybe their time horizon is too short, or maybe apart from financial issues they attach significant importance to other factors, such as the increase in the number of inhabitants, which they may treat as a confirmation of good municipal management. Certainly, a different method of analysing data is also crucial. Scientists prefer analyses made with reference to relative measures, i.e. income or expenses per capita, while in everyday life people, including municipal authorities, think more in absolute terms. For example, an increase in the number of inhabitants and revenues by e.g. $25 \%$ will not change the income per capita, but undoubtedly the municipality will be richer and the situation of its authorities and inhabitants will be more comfortable, if only because its current debt per capita will drop ${ }^{4}$.

It is difficult to assess clearly the balance of benefits and costs of city sprawl in relation to the financial situation of municipalities on a national scale. Undoubtedly, the income of local government units is growing, and this happens for two main reasons. Firstly, houses in the suburbs are bigger than in the cities, so with the property tax, where the tax base is determined by the area of the house and not its value, it generates higher income from this tax. Secondly, new settlement often takes place in areas where previously agricultural activity was carried out, which it is not subject to income tax in Poland. The agricultural tax, which can be treated as a substitute for the real estate tax, has very low rates, and land classified as the fifth or the sixth grade is exempt from this tax. For example, for a municipality, a conversion of a field (with the highest tax rate) into a warehouse plot means an increase in real estate tax income from one square meter by almost 1250 times!

\footnotetext{
4 Of course, the debt may increase in the future, e.g. due to the pressure of new residents on infrastructural investments, but this does not change the fact that, ceteris paribus, an increase in the number of residents means a decrease in debt per capita at a given moment.
} 
Allocating this land to building plots means an increase in the municipality's income by more than 25 times, and to residential buildings by more than 41 times [ $\ell u k o m-$ ska, Neneman, 2020]. Such a great diversification of LGU's revenues from land taxation is a powerful stimulus encouraging local authorities to support the settlement, even the dispersed one. The increase in the municipality's population density and thus its revenues means a lower level of subsidies available for such a settlement municipality. For such municipalities, this is obviously a loss, however from the point of view of public finances, it is an undeniable benefit. On the expenditure side, regardless of the nature of new settlements, the population density in suburban municipalities is generally lower than in cities, and this results in a significant increase in the cost of providing public services [EEA, 2006; Hortas-Rico, Solé-Ollé, 2008; Ida, Ono, 2013]. In Poland, Śleszyński [2018, p. 70] analysed higher infrastructure costs in the example of construction and maintenance of water supply systems. While in cities, 2 meters of a water supply system is sufficient to serve $90 \%$ of the population, in suburban areas 8.5 meters of water supply system is required for the same purpose.

It is impossible to estimate the balance of additional income and supplementary costs of all local government units resulting from the city sprawl. The certain element is the geographical change in income tax distribution (i.e. different division of the same cake) and a slight increase in revenues resulting from larger size of real estate. In Polish conditions in particular, there is also significantly higher revenues associated with the conversion of agricultural land for housing development, however this is primarily due to the imprefect system of agriculture taxation. From the point of view of a municipality, this constitutes a strong incentive for suburbanisation. The second motivation results from the fact that a part of the public costs of suburbanisation does not affect the beneficiaries of this phenomenon. When examining limiting or at least "taming" this phenomenon, it is necessary to remember those stimuli that clearly influence the policy of municipalities.

\section{Research data and methodology}

This article focuses on the effects of suburbanisation processes, which are reflected in municipal budgets. The empirical analysis uses financial data from financial reports on the execution of municipal budgets during the period 2004-2018 received by the Ministry of Finance. The analysis covers all municipalities in Poland, excluding cities with county status. To identify the group of suburban municipalities the delimitation developed by Śleszyński [2013] was used.

The analysis focuses on changes that have occurred in the financial situation of suburban municipalities (excluding cities with county status), which are compared with the changes in other municipalities. The financial situation is analysed through the perspective of those elements of municipalities' budgets where a clear impact of population changes (resulting from suburbanisation) was anticipated. Firstly, the revenue aspect was evaluated, and more specifically, revenues generated by munici- 
palities themselves. It is expected that in suburban municipalities the growth of own revenues per capita in the analysed period is higher than in other municipalities (mainly due to higher revenues from PIT and real estate taxes). Next, the expenditure side was analysed in terms of current expenditures, followed by the current budget result, i.e. the operating surplus. The gross value of this indicator was primarily used, although the analysis also referred to the net operating surplus. Finally, the analysis included the investment expenditures of municipalities.

The analysis method is the difference-in-differences (DiD) regression models, often used to study relationships in time between groups of individuals [Angrist, Pischke, 2008]. In the case of this method, there is no control over the process of selecting units for the study group, as it is usually fixed "in advance", e.g. municipalities that have been subject to a specific reform or support program. In our case, these are the municipalities delimited as agglomeration municipalities subjected to suburbanisation processes. The DiD analysis is based on comparing the differences in the values of the examined target variables over time between the entities subjected to the intervention ("experimental" group) and those not subjected to it, which serve as a control group. In the case of this study, the suburbanisation process is the intervention. Our analysis covers the years $2004-2018^{5}$, and it is difficult to indicate the exact moment of intervention/reforms. Suburbanisation is a continuous process, therefore we analysed the effect of the difference for the examined results (concerning the financial situation) between suburban and other municipalities in the whole period mentioned above, referring to 2004 as the base year. Furthermore, since the municipalities belonging to particular groups significantly differ in size (number of inhabitants), which is an important feature for the budget variables which were examined, we decided to control it directly in the models.

The estimation was made using regression models with standard fixed effects (FE) described in the following equation:

$$
Y_{i j}=b_{0}+b_{g} G_{i j}+b_{t} T_{j}+b_{g t}\left(G T_{i}\right)+b_{L} L_{i j}+\varepsilon_{i j}
$$

where,

$\mathrm{Y}_{\mathrm{ij}}$ - dependant variable in the i municipality and in the $j$ year,

$\mathrm{G}_{\mathrm{ij}}$ - zero-one variable describing the fact of belonging of the $\mathrm{i}$ municipality in $j$ year to the group of suburban municipalities $(G=1)$ or to the control group, i.e. the remaining municipalities, without cities with county status $(G=0)$

$\mathrm{T}_{j}$ - dummy variable describing the year of observation ( $\mathrm{T}=0$ for $2004, \mathrm{~T}=1$ for 2005, 2006, 2007, ... etc.),

$\mathrm{GT}_{\mathrm{i}}$ - interaction of time and intervention (DiD estimator),

$\mathrm{L}_{\mathrm{ij}}$ - the size of the i municipality in the $\mathrm{j}$ year,

$\varepsilon_{i j}-\quad$ random element,

$\mathrm{b}_{0}$ - parameter describing the average value of the dependent variable in 2004 in the control group

\footnotetext{
${ }^{5}$ For some supplementary analyses, the period covers only the years 2011-2018.
} 
$\mathrm{b}_{\mathrm{g}}$ - parameter describing the difference in averages between the two groups in 2004,

$\mathrm{b}_{\mathrm{t}}-$ parameter describing the difference of average values of parameters between 2004 and year $\mathrm{T}=1$ in the control group

$\mathrm{b}_{\mathrm{gt}}-$ parameter describing to what extent the change between years differed between the group of suburban municipalities and the control group

In order to take into account the data structure, an estimation correction of clustered-robust standard errors was applied, related to groupings of observations by municipalities. Dependent variables in subsequent models are: municipalities own revenues per capita, municipalities current expenditure per capita, municipalities operating surplus per capita, municipalities investment expenditure per capita.

\section{Research results}

In the period 2004-2018, the actual total own revenues (including shares in central taxes) of the suburban municipalities of the largest agglomerations increased by $139 \%$, while total own revenues of the remaining municipalities (excluding cities with county status) increased by $106 \%$ (chart 1 ). It should also be noted that at the same time, the number of residents served by local governments increased significantly in suburban areas (by ca. 16\%). In the remaining municipalities the number of inhabitants did not change during the analysed period (chart 2).

CHART 1

\section{Change of own revenues in the group of suburban municipalities and in other municipalities (excluding cities with county status, in fixed prices, $2004=100$ )}

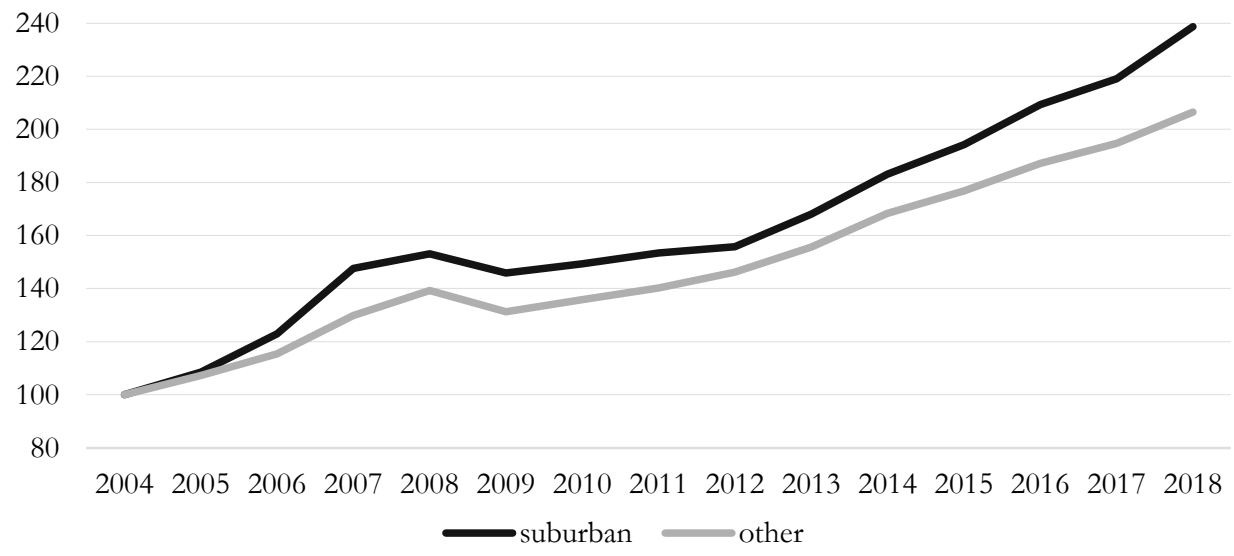

Source: own calculations based on data from local governments' budget execution reports provided by the Ministry of Finance [www 1; www2]. 
CHART 2

Change of inhabitant's number in the group of suburban municipalities and in other municipalities (excluding cities with county status, 2004=100)

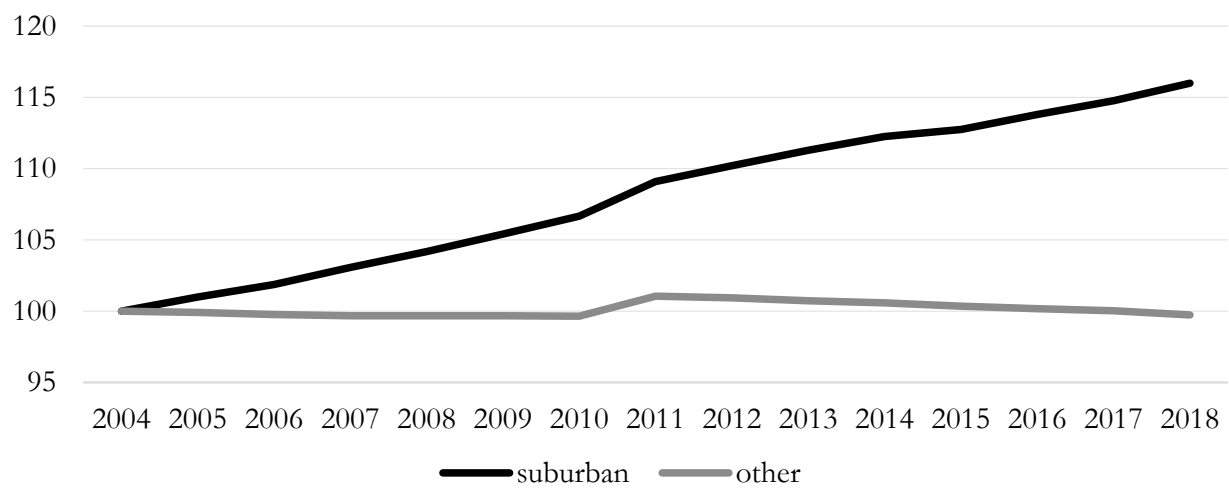

Source: own calculations based on data from local governments' budget execution reports provided by the Ministry of Finance [www 1; www2].

The trend of changes in own revenues per capita in suburban municipalities did not differ significantly from that in other municipalities. Until 2011, per capita revenues in agglomeration areas grew slightly faster than in the remaining municipalities, but since 2012 this situation has reversed (chart 3).

CHART 3

Change of own revenues per capita in the group of suburban municipalities and in other municipalities (excluding cities with county status, in fixed prices, 2004 $=100$ )

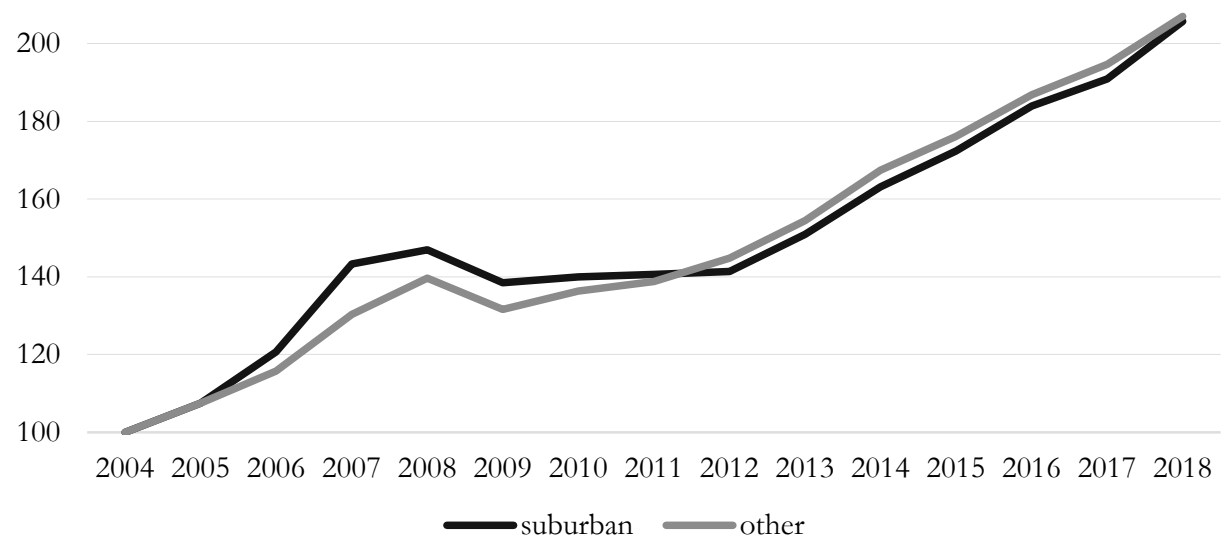

Source: own calculations based on data from local governments' budget execution reports provided by the Ministry of Finance [www 1; www2]. 
New residents in suburban areas "bring with them" additional revenues to the local budget, mainly in the form of their participation in the central PIT and real estate tax (when they purchase an agricultural land and build a house on the plot). The share of revenues from PIT in the structure of own revenues increased in all municipalities in Poland, however, in the case of suburban municipalities this increase was slightly more pronounced in comparison with other municipalities (in the period 2004-2018: by 13 percentage points in suburban municipalities; by 11 percentage points in other municipalities). At the same time, the significance of real estate tax revenues in the own revenues of municipal budgets generally declined, both in suburban and other municipalities, by about 8 percentage points (table 1).

TABLE 1

Share of revenues from PIT and real estate tax in own revenues of suburban municipalities and other municipalities in 2004-2018 (in \%)

\begin{tabular}{|c|c|c|c|c|c|c|c|c|c|c|c|c|c|c|c|}
\hline & ষ্ণ & ํํㅇ & ఫั่ & ণ্ণิ & 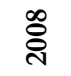 & ठ্ণิ & 웅 & $\overline{\overline{\overbrace{}}}$ & 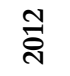 & 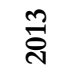 & 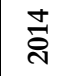 & 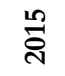 & 웅 & 곡 & $\stackrel{\infty}{\stackrel{\sim}{\sim}}$ \\
\hline \multicolumn{16}{|c|}{ Share of PIT in own revenues } \\
\hline $\begin{array}{l}\text { sub- } \\
\text { urban } \\
\mathrm{m} .\end{array}$ & 34.0 & 35.6 & 36.9 & 38.8 & 40.9 & 41.4 & 40.1 & 41.0 & 41.4 & 40.5 & 40.5 & 42.3 & 43.4 & 45.0 & 46.8 \\
\hline $\begin{array}{l}\text { other } \\
\mathrm{m} \text {. }\end{array}$ & 28.2 & 29.4 & 31.8 & 34.3 & 35.5 & 32.9 & 31.5 & 33.3 & 32.8 & 32.6 & 32.9 & 34.5 & 35.5 & 36.8 & 38.8 \\
\hline \multicolumn{16}{|c|}{ Share from real estate tax in own revenues } \\
\hline $\begin{array}{l}\text { sub- } \\
\text { urban } \\
\mathrm{m} .\end{array}$ & 32.4 & 32.3 & 29.1 & 24.9 & 24.8 & 27.5 & 27.7 & 28.4 & 29.2 & 28.9 & 27.6 & 27.3 & 26.6 & 26.1 & 24.8 \\
\hline $\begin{array}{l}\text { other } \\
\mathrm{m} \text {. }\end{array}$ & 36.0 & 35.1 & 33.7 & 30.5 & 28.6 & 30.8 & 31.0 & 30.9 & 31.0 & 30.9 & 29.9 & 29.7 & 29.0 & 29.1 & 27.7 \\
\hline
\end{tabular}

Source: own calculations based on data from local government' budget execution reports provided by the Ministry of Finance [www 1; www2].

The analysis of the level of own revenues per capita shows that in the entire analysed period 2004-2018, it was higher in the suburban municipalities in comparison within other municipalities. The difference between the two groups of identified municipalities was growing systematically until 2009, then it remained stable in the years 2010-2014, only to grow slowly again until 2018. During the 14 years of the analysed period, the own revenues of suburban municipalities increased by almost 500 PLN per capita more than in other municipalities, while controlling the population size of the municipality (chart 4). 
CHART 4

Estimated difference effect between own revenues per capita in suburban municipalities and other municipalities, while controlling the municipality size (excluding cities with county status, in PLN per capita)

700

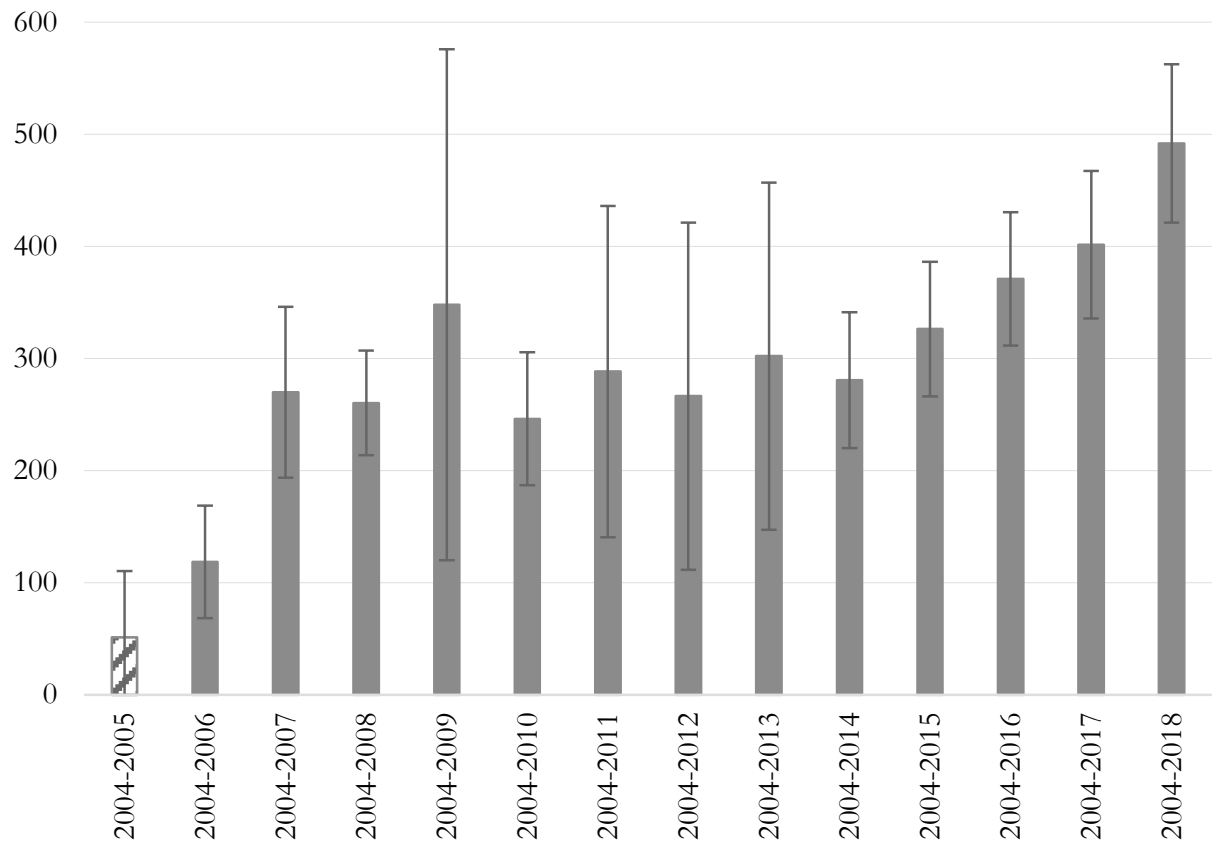

* the bars represent the regression coefficients $b_{g t}$ from the equation (1); the bars in full colour represent values significant at the level of 0.01 ; striped bars represent values significant at the level of 0.1 ; white bars represent insignificant values of coefficients.

Source: own calculations based on data from local governments' budget execution reports provided by the Ministry of Finance [www 1; www2].

A different effect of the city sprawl processes can be observed in relation to the spending side of municipal budgets, in particular with respect to the current expenditures. In almost the entire analysed period (with the exception of the final years under analysis), current expenditures per capita in suburban municipalities increased by a smaller amount than in other municipalities when compared to 2004, which confirms the occurrence of the economies of scale. The difference between the groups, while controlling the size of the municipality, was negative for the majority of the analysed period (it reached its minimum in the period 2004-2011, then it was over -100 PLN per capita) (chart 5). 
CHART 5

Estimated difference effect between current expenditure per capita in suburban municipalities and other municipalities, while controlling the municipality size (excluding cities with county status, in PLN per capita)

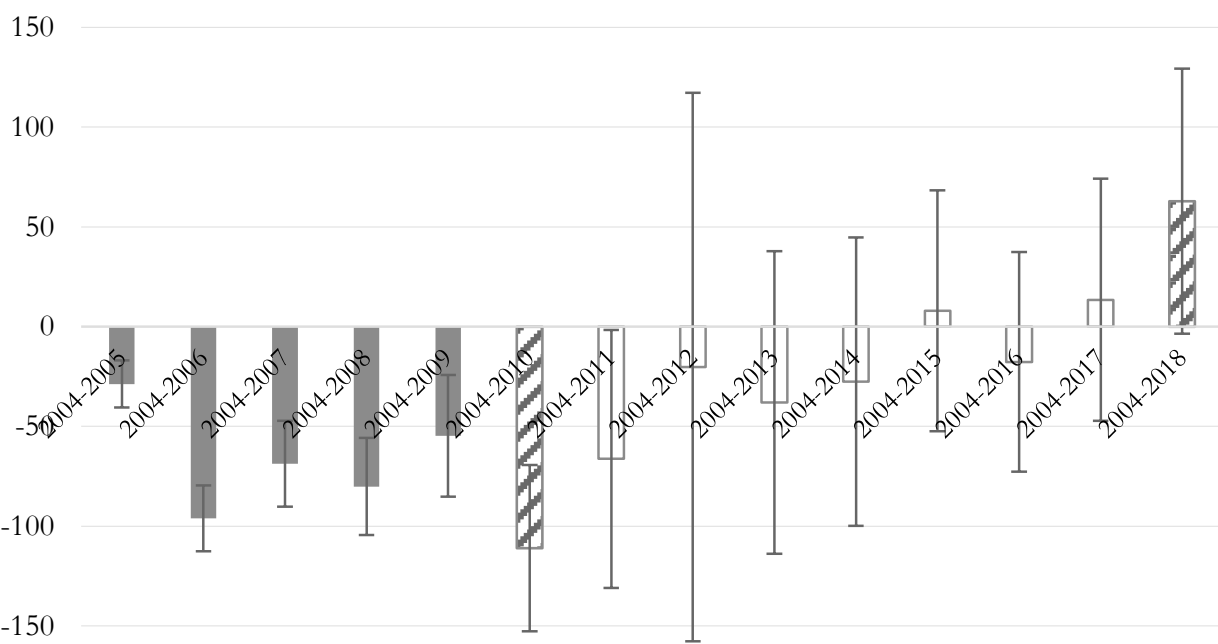

$-200$

* symbols explanation as in chart 4 .

Source: own calculations based on data from local governments' budget execution reports provided by the Ministry of Finance [www 1; www2].

The financial situation (measured by the budget operating surplus per capita) was more favourable in suburban municipalities than in other municipalities in the entire period under review. In the years 2004-2018, the operating surplus per capita in suburban municipalities was on average $50 \%$ higher than in the remaining municipalities (in 2004 it amounted to almost 290 PLN per capita in suburban municipalities and about 200 PLN in other municipalities). Moreover, in almost the entire analysed period (except for the period of economic slowdown, i.e. 2009 and 2012-2013), the current budget surplus grew faster in suburban areas than in other municipalities (chart 6).

The difference between the group of suburban municipalities and other municipalities concerning their budget operational surplus (while controlling the population size of the municipality) grew in the period 2004-2007 (in 2007 it reached as much as 185 PLN per capita) and in 2014-2018, i.e. in the times of relative stabilisation of the macroeconomic situation. In 2008-2013, although the difference was mostly positive (except for 2012), it showed a falling trend. On average, in the entire analysed period (in comparison to 2004), the surplus of current revenues over current expenditures was higher by about 85 PLN per capita in suburban municipalities than in other municipalities (chart 7). 
CHART 6

Changes of operating surplus per capita in the group of suburban municipalities and in other municipalities (excluding cities with county status, in fixed prices, $2004=100$ )

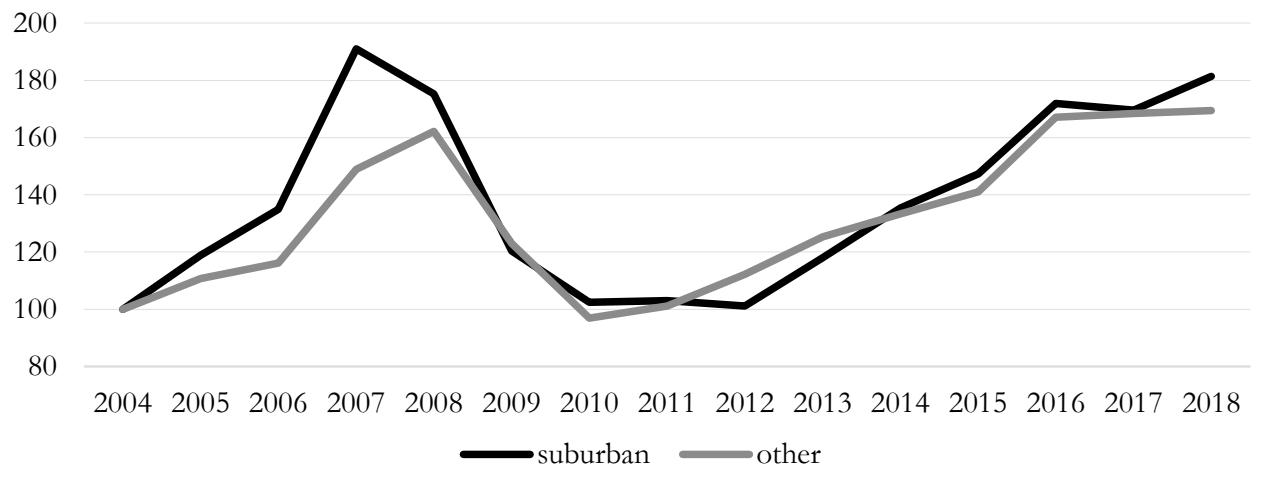

Source: own calculations based on data from local governments' budget execution reports provided by the Ministry of Finance [www 1; www2].

CHART 7

Estimated difference effect between operating surplus per capita in suburban municipalities and other municipalities, while controlling the municipality size (excluding cities with county status, in PLN per capita)*

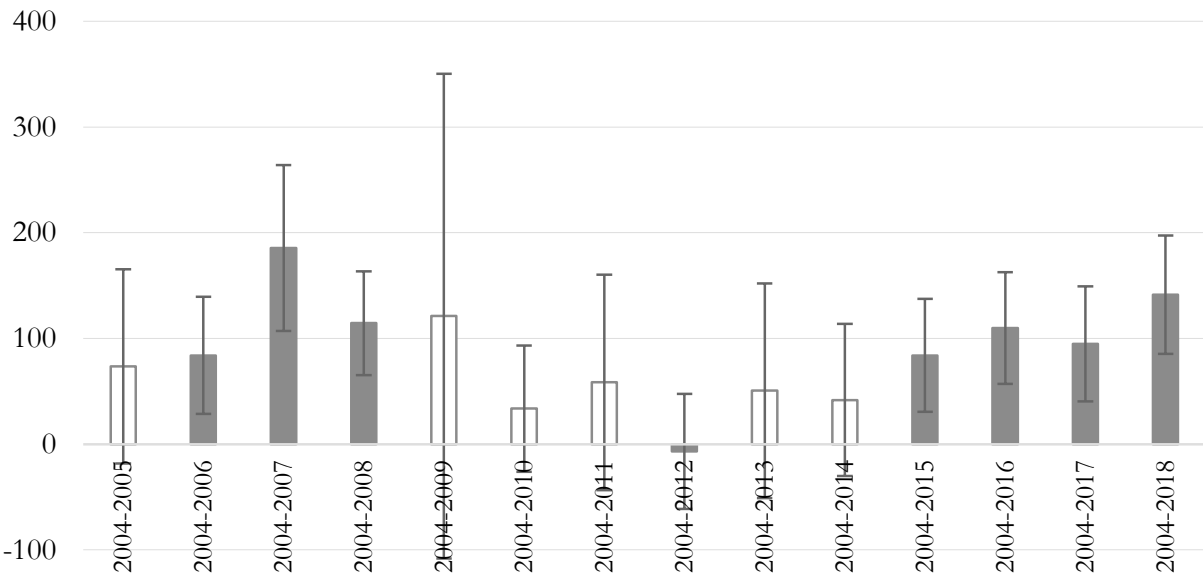

* symbols explanation as in chart 4 .

Source: own calculations based on data from local governments' budget execution reports provided by the Ministry of Finance [www 1; www2]. 
It is worth remembering, however, that local authorities do not have to allocate the operating surplus entirely for investment expenditures. Part of this free money is used for debt service (repayment of capital instalments on incurred liabilities). The question is whether suburban municipalities are different from other municipalities in this respect. The analysis of financial data for the last 8 years shows that suburban municipalities allocated a much smaller part of their operating surplus to debt service in comparison with other municipalities (by 15 percentage points less on average in the analysed period) (table 2).

TABLE 2

Change of share of funds allocated for debt service in the operating surplus in suburban municipalities and other municipalities in 2011-2018 (in \%)

\begin{tabular}{|l|c|c|c|c|c|c|c|c|}
\hline & $\mathbf{2 0 1 1}$ & $\mathbf{2 0 1 2}$ & $\mathbf{2 0 1 3}$ & $\mathbf{2 0 1 4}$ & $\mathbf{2 0 1 5}$ & $\mathbf{2 0 1 6}$ & $\mathbf{2 0 1 7}$ & $\mathbf{2 0 1 8}$ \\
\hline suburban m. & 40.7 & 42.7 & 40.5 & 30.4 & 31.3 & 27.2 & 25.4 & 24.3 \\
\hline other $\mathrm{m}$. & 67.8 & 68.1 & 64.1 & 39.4 & 44.6 & 33.3 & 31.1 & 34.2 \\
\hline
\end{tabular}

Source: own calculations based on data from local governments' budget execution reports provided by the Ministry of Finance [www 1; www2].

As a result, the difference between the suburban and other municipalities in terms of the net operating surplus (in PLN per capita) was therefore greater than in terms of gross operating surplus, as mentioned above. The conducted analyses suggest that in the evaluated period, as a result of the suburbanisation processes, the financial situation in terms of the current budget of suburban municipalities was more favourable than that of other municipalities (where the population remained relatively stable and they did not experience an influx of new residents).

The nature of the "sprawling agglomerations" certainly caused a great demand for new costly investments (roads, sewage systems, but also, e.g. kindergartens). Additionally, local authorities in suburban municipalities experienced pressure from "new residents" (who had previously lived in central cities and were accustomed to much better services of the municipal infrastructure) regarding the need for new

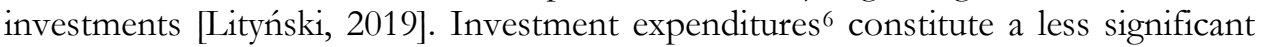
part of municipal expenditures than current expenditures (in 2018 they accounted for slightly more than $21 \%$ of total municipal expenditures). On average, between 2004-2018, suburban municipalities spent almost 30\% more per capita on investments than the other ones (680 PLN per capita in suburban municipalities compared to 534 PLN in other municipalities).

Throughout the entire period under examination (except for 2011), in relation to 2004, suburban municipalities invested more per capita than other municipalities. This difference increased in the years 2004-2008 and in the period 2015-2018, to reach over 300 PLN per capita (chart 8) at the end of the analysed period. This is

6 The analysis covered only investment expenditures financed from the municipality budget, excluding those financed by municipal companies (due to lack of access to relevant data). 
a result of what was pointed out by Smutek [2016] and Lityński [2019], when they wrote that investment expenditures per capita in suburban municipalities increase along with the population growth.

CHART 8

Estimated difference effect between investment expenditure per capita in suburban municipalities and other municipalities, while controlling the municipality size (excluding cities with county status, in PLN per capita)*

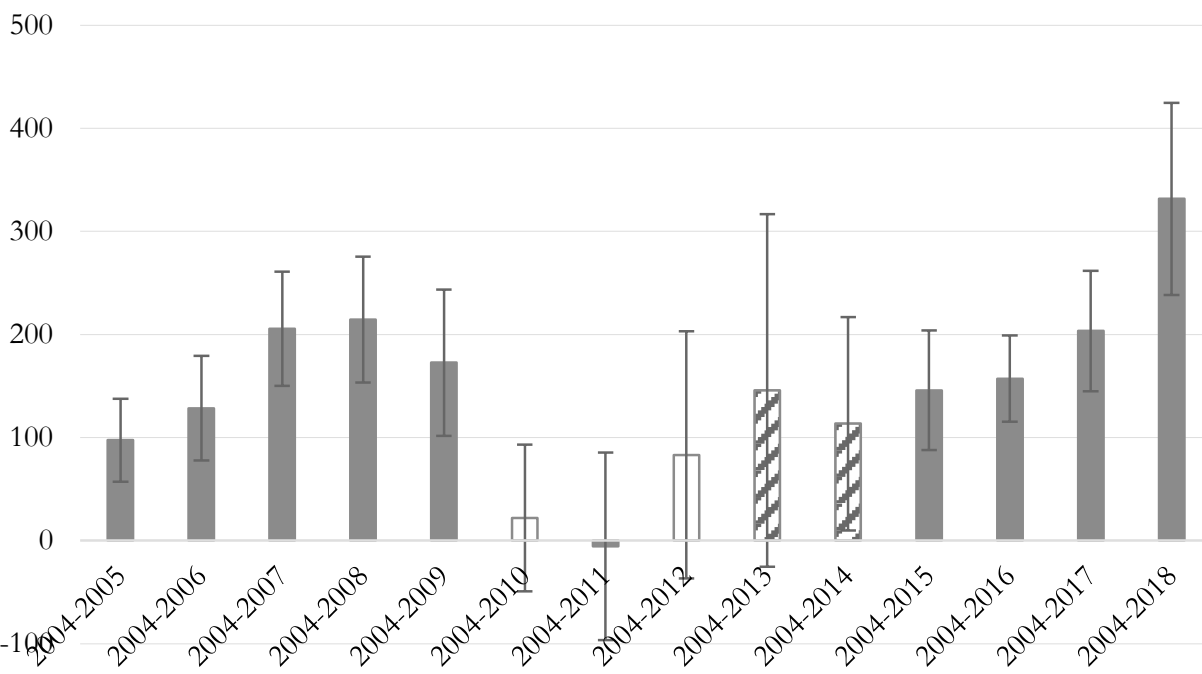

* symbols explanation as in chart 4 .

Source: own calculations based on data from local governments' budget execution reports provided by the Ministry of Finance [www 1; www2].

In order to verify what part of investment expenditures was realised from municipalities' own revenues (including the previously discussed net operating surplus), an analysis was made of the share of investment expenditures financed with the use of various types of grants (from the EU, the state budget, budgets of other LGUs or other institutions) in both groups of analysed municipalities. In the years 2011-2018, total investment grants accounted for $26.5 \%$ of all investment expenditures of suburban municipalities, while in other municipalities the share was as high as $36.6 \%$. In financing investment expenditures, suburban municipalities support themselves to a greater extent with their own funds as compared with other municipalities (their share of investment grants was on average about 10 percentage points lower than in other municipalities) (table 3). 
TABLE 3

Share of investment grants in all investment expenditure in suburban municipalities and other municipalities in 2011-2018 (in \%)

\begin{tabular}{|l|l|l|l|l|l|l|l|l|}
\hline & $\mathbf{2 0 1 1}$ & $\mathbf{2 0 1 2}$ & $\mathbf{2 0 1 3}$ & $\mathbf{2 0 1 4}$ & $\mathbf{2 0 1 5}$ & $\mathbf{2 0 1 6}$ & $\mathbf{2 0 1 7}$ & $\mathbf{2 0 1 8}$ \\
\hline suburban & 32.1 & 30.5 & 29.5 & 28.3 & 30.9 & 20.6 & 16.7 & 25.9 \\
\hline other & 42.9 & 48.3 & 39.8 & 36.3 & 45.7 & 26.4 & 22.6 & 31.6 \\
\hline
\end{tabular}

Source: own calculations based on data from local governments' budget execution reports provided by the Ministry of Finance [www 1; www2].

\section{Conclusions}

An analysis of the operating surplus of the current budget both in gross and even more so in net terms demonstrates that in suburban municipalities (experiencing an intensive inflow of people from central cities in the years 2004-2018) the financial situation was improving (and the distance was increasing) in comparison to other municipalities (excluding the period of economic slowdown). Therefore, it is not surprising that the development strategies of the suburban municipalities, often applied by the local authorities, are frequently based on attempts to attract as many inhabitants as possible.

The situation differed in the case of investment expenditures of municipalities. Due to the increase in the number of inhabitants and higher expectations as to the level of infrastructure, suburban municipalities allocated more to investments than other municipalities, and the difference between these groups has been systematically growing since 2012. Even if the amount of investment expenditures is reduced by the amount of funds obtained by the municipalities from the external sources under various types of investment grants (i.e. the analysis includes only the investment expenditures financed with municipalities own revenues or with the use of debt instruments), it seems that the suburban municipalities allocated the entire budget operating surplus (obtained to a large extent thanks to the "new residents") for increased investment expenditures. The situation was almost identical in other municipalities, however, their investment expenditures per capita were lower. This is justified because the financial situation of the current budgets of suburban municipalities in the analysed period was better, thus allowing for a greater investment effort and greater use of debt instruments (the total debt per capita in the years 2004-2018 was on average about 13\% higher in suburban municipalities than in other municipalities).

The urban sprawl is a beneficial phenomenon from the perspective of the financial situation of municipalities (where new residents are coming), at least in the short and medium term. Naturally, it is associated with a number of adverse effects (mainly environmental), however from the point of view of the narrowly understood financial interest of the municipality, the final outcome is positive. Therefore, any attempts, which are socially necessary, to limit and control this phenomenon 
will meet strong resistance of municipalities benefiting from urban sprawl. Legal changes aimed at limiting and organising the suburbanisation process must therefore be accompanied by changes in economic incentives which would limit the financial attractiveness for suburban municipalities related to such type of settlement.

\section{References}

Angrist J.D., Pischke J.S., 2008, Mostly harmless econometrics: An empiricist's companion. Princeton University Press, Princeton.

Brueckner J.K., 2001, Urban sprawl: lessons from urban economics, [in:] Gale W.G., Rothenberg Pack J. (eds.), Brookings-Wharton Papers on Urban Affairs, DC: Brookings Institution, Washington.

Burchell R., Lowenstein G., Dolphin W., Galley C., Downs A., Seskin S., Gray Still K., Moore T., 2002, Cost of sprawl - 2000, TCRP Report 74, National Academy Press, Washington, D.C.

EEA, 2006, Urban sprawl in Europe. The ignored challenge, Report no. 10, European Commission.

Elis-Williams D.G., 1987, The effect of spatial population distribution on the cost of delivering local services, "Journal of the Royal Statistical Society", vol. 150(2), pp. 152-166.

Gliwiński M., 2018, Prayccynny i skutki niekontrolowanej suburbanizacji, CEO.com.pl. Biznes w praktyce, https://ceo.com.pl/przyczyny-i-skutki-niekontrolowanejsuburbanizacji-73262, [date of entry: 07.06.2019].

Hortas-Rico M., Solé-Ollé A., 2008, Does Urban Sprawl Increase the Cost of Providing Local Public Services? Evidence from Spanish Municipalities, „Urban Studies”, vol. 47(7), pp. 1513-1540, DOI: 10.1177/0042098009353620.

Humer A., Sedlitzky R., Brunner D., 2019, When does population growth pay off? A case study of suburban land consumption to assess the Lower Austrian infrastructural cost calculator, "Journal of Housing and the Built Environment", vol. 34, pp. 331-344, DOI: 10.1007/s10901-018-09639-7.

Ida T., Ono H., 2013, Urban sprawl and local governmental cost in Japan, The 6th Australasian Public Choice Conference, https://economics.smu.edu.sg/sites/ default/files/economics/Events/APCC2013/Papers/6Dec/4_tomoyaida.pdf [date of entry: 12.02.2020].

Kowalewski A., Mordasewicz J., Regulski J., Stępień J., Śleszyński P., 2014, Ekonomiczne straty $i$ spoteczne kosaty niekontrolowanej urbanizacji w Polsce - wybrane fragmenty raportu, „Samorząd terytorialny”, nr 4, s. 5-21.

Lisowski A., Grochowski M., 2008, Procesy suburbanizacji: uwarunkowania, formy i konsekwencje, Wystapienie na seminarium: Problematyka rozwoju obszarów miejskich, w tym obszarów metropolitalnych w Koncepcji Prz̨estrzennego Zagospodarowania Kraju 2008-2033, Ministerstwo Rozwoju Regionalnego, Warszawa.

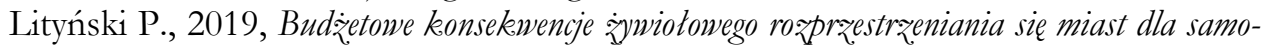
rzadów gminnych, Wydawnictwo UE w Krakowie, Kraków. 
Lityński P., Hołuj A., 2017, Urban sprawl cost: the valuation of households' losses in Poland, "Journal of Settlements and Spatial Planning", vol. 8, no. 1, pp. 11-35, DOI: 10.24193/02JSSP012017.

Lukomska J., Neneman J., 2019, Fiskalne konsekwencje rozlewanie miast - praypadek. Miejskiego Obszaru Funkecjonalnego - Lublin, [w:] Szołno-Koguc J., Śmiechowicz J. (red.), Dochody podatkowe samorzadu terytorialnego i csynniki je ksztattujace, Wydawnictwo UMCS, Lublin.

Lukomska J., Neneman J., 2020, Koszty i korzyśsi dez-i suburbanizacii - perspektywa jednostek samorzadu terytorialnego, [w:] Gawrońska-Nowak B. (red.) Analiza syskón i strat sub/dezurbanizacji w swietle badan spokecznych, Wydawnictwo Naukowe Instytutu Rozwoju Miast i Regionów, Kraków (w druku).

McGuire T.J., Sjoquist D.L., 2002, Urban Sprawl and the Finances of State and Local Governments, [in:] Sjoquist D.L. (ed.) State and Local Finances Under Pressure, Edward Elgar, UK, USA.

Nowak P., 2015, Eksurbanizacja wspótczesnych miast, „Studia Miejskie”, tom 20, s. 133-140.

Orfield M., 2002, American Metropolitics. The new suburban reality, Brookings Institution Press, Washington.

Śleszyński P., 2013, Delimitacja miejskich obszarón funkcionalnych stolic wojewódzțw, „Przegląd Geograficzny", nr 85(2), s. 173-197.

Śleszyński P., 2018, Spoteczno-ekonomiczne skutki chaosu przestrzennego dla osadnictwa i struktury funkcjonalnej terenów, „Studia KPZK”, t. 182, s. 29-80.

Smutek J., 2016, Wptyw suburbanizacii na budzety gmin w strefie oddziatywania wielkich miast w Polsce, Praca doktorska, Uniwersytet Szczeciński, Szczecin.

www 1, https://www.gov.pl/web/finanse/sprawozdania-budzetowe [date of entry: 05.04.2020].

www 2, https://mf-arch2.mf.gov.pl/web/bip/ministerstwo-finansow/dzialalnosc/ finanse-publiczne/budzety-jednostek-samorzadu-terytorialnego/sprawozdaniabudzetowe [date of entry: 05.04.2020]. 